\title{
Granulomatous reaction secondary to intramammary silicone injection
}

\author{
Sharifah Majedah Idrus Alhabshi, Sarina Salim
}

Department of Radiology, University Kebangsaan Malaysia Medical Centre, Kuala Lumpur, Malaysia

\section{Correspondence to}

Dr Sharifah Majedah, shmajedah@yahoo.com
To cite: Majedah S

Alhabshi I, Salim S. BMJ

Case Rep Published online: [please include Day Month Year] doi:10.1136/bcr-2012007961

\section{DESCRIPTION}

A 54-year-old woman complained of bilateral breast lumps for 8 years. She noted this problem after silicone injection was given into her breasts for breast augmentation about 10 years ago.

The lumps were not increasing in size and were occasionally painful. On clinical assessment, both breasts were lumpy and occasionally tender on palpation. There were no enlarged axillary lymph nodes.

Mammogram showed (figure 1) ill-defined highdensity masses of variable size in both breasts and predominantly at the retro-mammary region. There was no suspicious cluster of microcalcifications. Ultrasound examination showed that the breast parenchymal was largely obscured by posterior acoustic shadow casted by these masses resulting in poor visualisation of the normal breast parenchymal pattern or any underlying abnormality (figure 2).

An MRI of the breast was performed for further assessment (figure 3). There were multiple irregular lesions in both the breasts which show variable signal intensity. They predominantly showed relatively low signal intensities on $\mathrm{T} 1$ sequences and high signal on T2. These rounded lesions were associated with hypointense rims in all the sequences. Dynamic enhancement curve showed type 1 kinetic enhancement which was consistent with benign breast lesion. None of these lesions showed enhancement in post-gadolinium images. There was no suspicious lesion in both the breasts and no axillary lymphadenopathy.

Fine needle aspiration cytology (FNAC) was conducted for palpable lesions in both breasts and confirmed to be granulomatous reaction secondary to intramammary silicone injection.

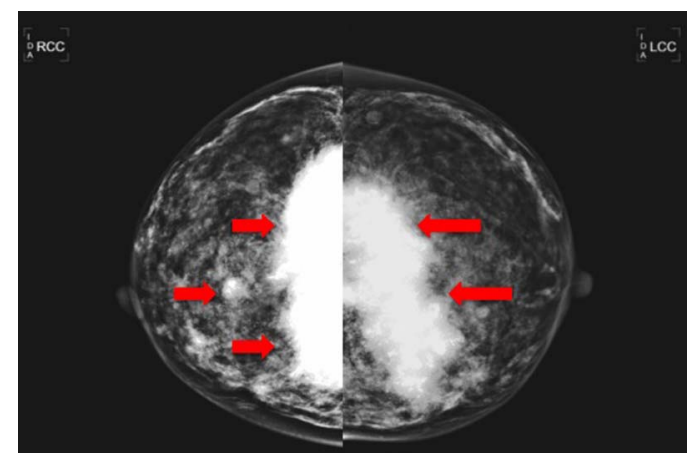

Figure 2 Bilateral mammogram cranial caudal view showed scattered irregular high-density masses in both breast predominantly at the retromammary region (arrows).

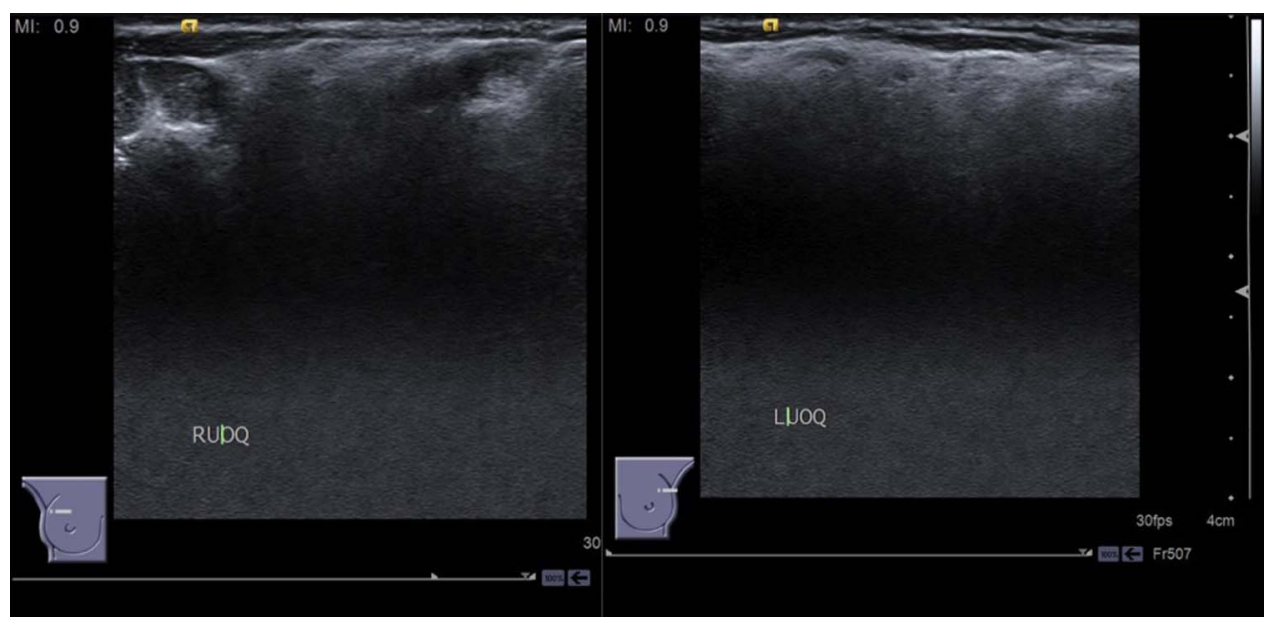

Figure 1 Ultrasound of both breast bilaterally showed strong posterior acoustic shadow obscuring the underlying breast tissue. 


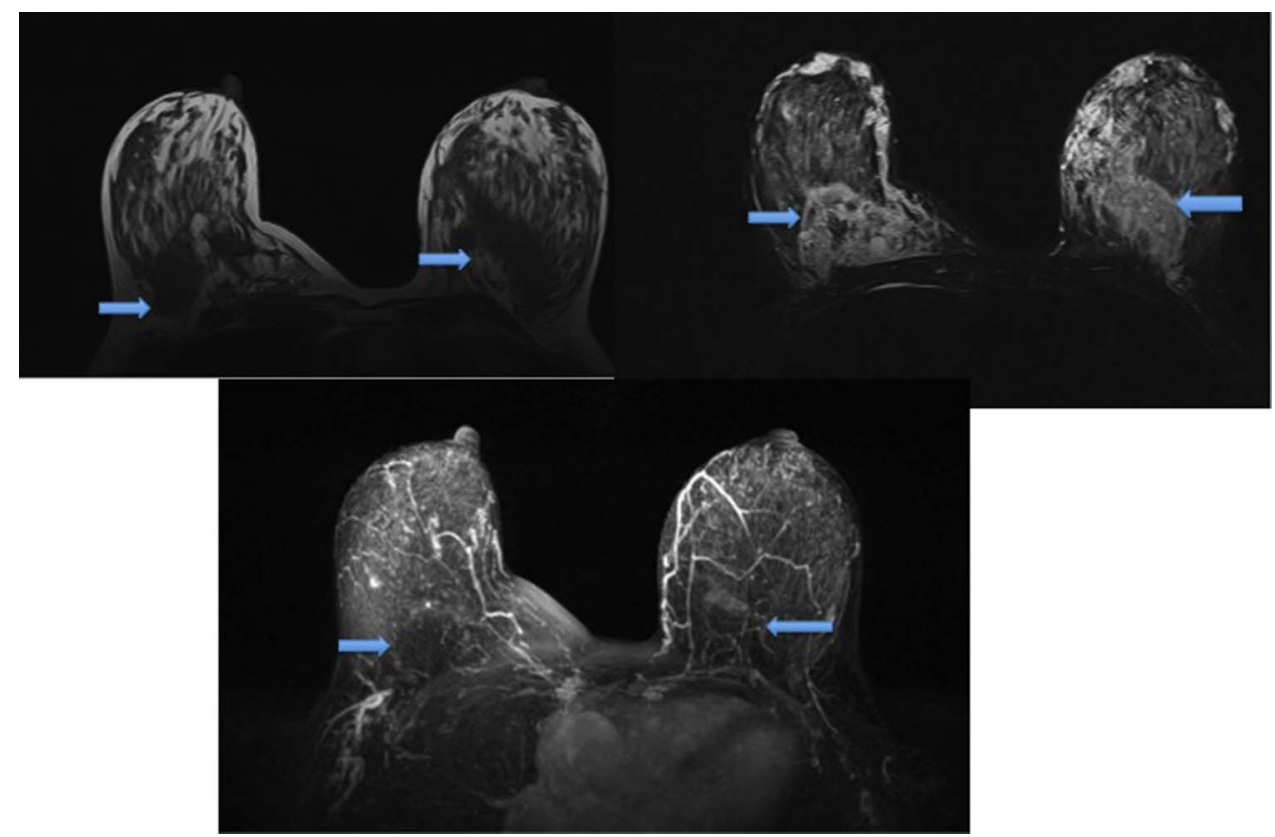

Figure 3 MRI (1) axial T1-weighted image showed irregular low-intensity scattered in both breasts predominantly at the retromammary region (arrow). (2) Axial T2-weighted image showed these masses predominantly high-to-intermediate signal intensity to glandular tissue (arrow). (3) Three-dimensional subtraction maximum-intensity projection axial view showed non-enhancing masses scattered in both breasts (arrow).

\section{Learning points}

- The US Food and Drug Administration never approved silicone for breast augmentation. Nevertheless, this inexpensive technique is still used, particularly in the developing countries. The common complications after breast augmentation include local inflammatory reactions, autoimmune reactions and migration of silicone fluid to axillary node. ${ }^{12}$ Therefore, it is important for the radiologist and breast surgeons to identify these complications, especially patients from Southeast Asia who had undergone illegal breast augmentation.

- The diagnosis of silicone granulomas can be made by mammography and ultrasound. ${ }^{2}$ However, to rule out carcinoma is limited because it is difficult to differentiate the granulomas from masses of breast parenchyma and these dense nodules tend to obscure the underlying breast parenchyma.

- Although MRI with dynamic signal intensity time curves can help to identify the internal architecture of silicon-injected breasts. Unfortunately, the differentiation of benign and malignant-enhanced lesions is also difficult but it can be used for identification of the optimal site for tissue diagnosis. $^{2} 3$
Competing interests None.

Patient consent Obtained.

Provenance and peer review Not commissioned; externally peer reviewed.

\section{REFERENCES}

1 Cheunga YC, Suc MY, Nga SH, et al. Lumpy silicone-injected breasts enhanced MRI and microscopic correlation. J Clin Imaging 2002;26:397-404.

2 Helbich $\mathrm{TH}$, Wunderbaldinger $\mathrm{P}$, Plenk $\mathrm{H}$, et al. The value of MRI in silicone granuloma of the breast. Eur J Radiol 1997;24:155-8.

3 Chen TH. Silicone injection granulomas of the breast: treatment by subcutaneous mastectomy and immediate subpectoral breast implant. BR J Plastic Surg 1995;48:71-6. 
Copyright 2013 BMJ Publishing Group. All rights reserved. For permission to reuse any of this content visit http://group.bmj.com/group/rights-licensing/permissions.

BMJ Case Report Fellows may re-use this article for personal use and teaching without any further permission.

Become a Fellow of BMJ Case Reports today and you can:

- Submit as many cases as you like

- Enjoy fast sympathetic peer review and rapid publication of accepted articles

- Access all the published articles

- Re-use any of the published material for personal use and teaching without further permission

For information on Institutional Fellowships contact consortiasales@bmjgroup.com

Visit casereports.bmj.com for more articles like this and to become a Fellow 